\title{
STRATEGI KEBIJAKAN PENGEMBANGAN SAGU BERBASIS SENTRA INDUSTRI KECIL MENENGAH (IKM)
}

\author{
Amir Syamsuadi ${ }^{1}$, Seri Hartati ${ }^{2}$, Liza Trisnawati $^{3}$, Diki Arisandi ${ }^{4}$ \\ ${ }^{1}$ Fakultas Ilmu Sosial dan Ilmu Politik, Universitas Abdurrab \\ Korespondensi email: amir.syamsuadi@univrab.ac.id \\ ${ }^{2}$ Fakultas Ilmu Sosial dan Ilmu Politik, Universitas Abdurrab \\ email: seri.hartati@univrab.ac.id \\ ${ }^{3}$ Fakultas Teknik, Universitas Abdurrab \\ email: liza.trisnawati@univrab.ac.id \\ ${ }^{4}$ Fakultas Teknik, Universitas Abdurrab \\ email:diki@univrab.ac.id
}

\begin{abstract}
Based on estate statistics collected by the Ministry of Agriculture of the Republic of Indonesia, that in 2017 the total area of plantations producing Sago Islands Regency reaches 91,944 hectares and plant production of 418,802 tons. The number increased from 2 years earlier, namely in 2015 sago plant area was 83,691 ha with a production yield of 366,032 tons and in 2016 sago plant area was 89,611 ha with a production yield of 377,914 . This study tries to trace the direction of the sago-based policy development Center for Small and Medium Industries in the Meranti Islands District. This research was conducted with a qualitative approach which is research that focuses on the concepts that arise from the data. The results of the analysis and interpretation of data in the form of exposure to the situation under study and then given a narrative and systematic explanation. The results showed that policies in order to encourage the development of sago-based Small and Medium Industrial Centers in the Regency of Meranti Islands including carried out with scenarios of structuring the location of activities, land use plans, efforts to map the transportation network system plans, telecommunications, electricity and clean water.
\end{abstract}

Keyword: policy; developmen; industry; sago.

\begin{abstract}
ABSTRAK
Berdasarkan data statistik perkebunan yang dihimpun oleh Kementerian Pertanian Republik Indonesia, bahwa pada tahun 2017 jumlah total luas tanaman menghasilkan sagu Kabupaten Kepulauan Meranti mencapai seluas 91.944 Ha dan produksi tanaman sebesar 418.802 ton. Jumlah tersebut meningkat dari 2 tahun sebelumnya, yakni tahun 2015 luas tanaman sagu 83.691 Ha dengan hasil produksi 366.032 Ton dan tahun 2016 luas tanaman sagu 89.611 Ha dengan hasil produksi sebesar 377.914. Penelitian ini mencoba menelusuri arah kebijakan pengembangan sagu berbasis Sentra Industri Kecil Menengah di Kabupaten Kepulauan Meranti. Penelitian ini dilakukan dengan pendekatan kualitatif yakni penelitian yang memusatkan perhatian kepada konsep-konsep yang timbul dari data. Hasil analisis dan interpretasi data berupa pemaparan mengenai situasi yang diteliti dan kemudian diberikan penjelasan secara naratif dan tersistematis. Hasil Penelitian menunjukkan bahwa kebijakan dalam rangka mendorong terciptanya pengembangan sagu berbasis Sentra Industri Kecil Menengah di Kabupaten Kepulauan Meranti diantaranya dilakukan dengan skenario penataan lokasi kegiatan, rencana penggunaan lahan, upaya pemetaan rencana sistem jaringan transportasi, telekomunikasi, listrik dan air bersih.
\end{abstract}

Kata Kunci: kebijakan; pengembangan; industri; sagu. 


\section{PENDAHULUAN}

Sagu (Metroxylon sp.) merupakan salah satu sumber karbohidrat yang layak untuk dikembangkan dalam rangka mencapai ketahanan pangan. Tanaman sagu sangat potensial untuk dikembangkan sebagai bahan pangan alternatif bagi masyarakat Indonesia selain padi (Kusuma et al., 2013). Kabupaten Kepulauan Meranti Provinsi Riau merupakan salah satu Kawasan Pengembangan Ketahanan pangan nasional karena sebagai salah satu penghasil sagu terbesar di Indonesia, bahkan Gubernur Riau telah menobatkan bahwa Kabupaten Kepulauan Meranti sebagai pusat pengembangan tanaman sagu secara nasional (Nursodik, Rosnita, dan Sayamar, 2016). Untuk melihat luas areal dan produksi sagu Provinsi Riau dan status pengusahaanya Tahun 2015-2017 dapat dilihat pada gambar berikut ini:

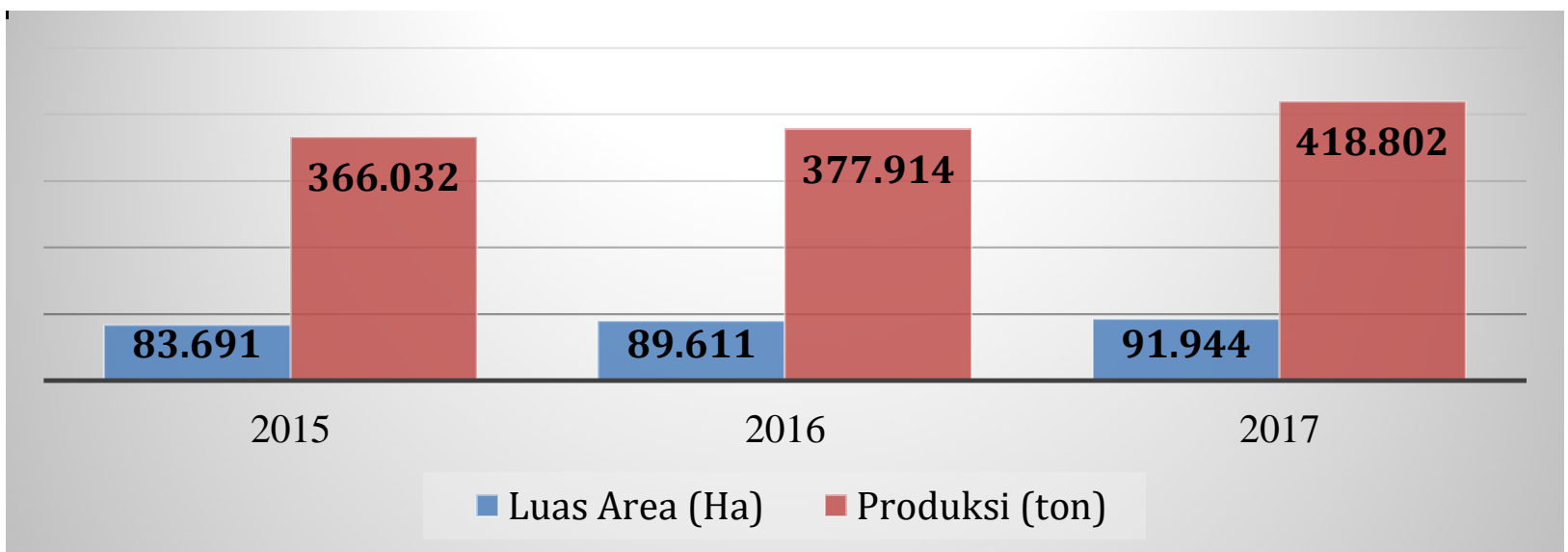

Gambar.1 Diagram Luas Areal dan Produksi Sagu Provinsi Riau dan Status Pengusahaanya Tahun 2015-2017 Sumber: (Direktorat Jendral Kementerian Pertanian Republik Indonesia, 2016)

Dari tujuh komoditas perkebunan di Kabupaten Kepulauan Meranti, Sagu mendominasi $77 \%$ dari total produksi sektor perkebunan. Luas area tanaman sagu rakyat di Kepulauan Meranti 42,130 Ha, yakni sekitar 2,98 persen luas tanaman sagu nasional (Aprilianti dan Yuliani, 2017). Untuk melihat potensi sagu tanaman Rakyat di Kabupaten Kepulauan Meranti tahun 2016 dapat dilihat pada tabel berikut ini:

Tabel 1. Potensi Sagu Tanaman Rakyat di Kabupaten Kepulauan Meranti tahun 2016

\begin{tabular}{llcccccc}
\hline No & Kecamatan & $\begin{array}{c}\text { Tbm } \\
\mathbf{( H a )}\end{array}$ & $\begin{array}{c}\text { Tm } \\
\mathbf{( H a )}\end{array}$ & $\begin{array}{c}\text { Jumlah } \\
\mathbf{( H a )}\end{array}$ & $\begin{array}{c}\text { Petani } \\
\text { (KK) }\end{array}$ & $\begin{array}{c}\text { Produktivitas } \\
\text { (Ton/Th) }\end{array}$ & $\begin{array}{c}\text { Jumlah } \\
\text { kilang } \\
\text { (unit) }\end{array}$ \\
\hline 1 & Tebing Tinggi & 50 & 306 & 356 & 70 & 2.754 & 3 \\
2 & T. Tinggi barat & 2.204 & 6.813 & 9.017 & 340 & 61.317 & 32 \\
3 & Rangsang & 261 & 262 & 523 & 749 & 2.358 & 1 \\
4 & Rangsang Barat & - & 165 & 165 & 170 & 1.485 & - \\
5 & Merbau & 3.756 & 1.465 & 5.221 & 789 & 13.185 & 5 \\
6 & T. Tinggi Timur & 8.638 & 7.946 & 16.584 & 1.068 & 71.514 & 17 \\
7 & Pulau Merbau & 387 & 801 & 1.188 & 703 & 7.209 & 1 \\
8 & Rangsang Pesisir & 606 & 1.615 & 2.221 & 2.144 & 14.535 & 4 \\
9 & Tasik Putri Puyu & 479 & 2.645 & 3.124 & 733 & 23.805 & 4 \\
& $\quad$ Jumlah & 16.381 & 22.018 & 38.399 & 6.766 & 198.162 & 67 \\
\hline
\end{tabular}

Sumber: (Direktorat Jendral Kementerian Pertanian Republik Indonesia, 2016)

Tanaman sagu di Kabupaten Kepulauan Meranti telah berkembang dan dimanfaatkan masyarakat sejak lama, dan mempunyai nilai ekonomi yang cukup membantu masyarakat di sekitar kawasan sagu (Novarianto et al., 2014). Sagu di 
Kabupaten Kepulauan Meranti bukanlah tumbuhan hutan liar seperti di Papua dan Maluku. Batas-batas tanah telah disepakati oleh pemilik dan pemerintah. Sebagian petani yang hanya memiliki luas tanah kurang dari 20 Ha biasanya menjual sagu batangan kepada pemilik kilang sagu (pabrik pengolahan) dan sebagian ada yang menitip olah dan kemudian hasilnya dibagi sesuai kesepakatan dengan pemilik kilang.

Perkebunan sagu rakyat di Meranti masih dibudidayakan secara tradisional. Hal ini bisa dilihat dari kerapatan tanaman sagu pada perkebunan rakyat. Jarak tanaman yang terlalu rapat mengakibatkan kurangnya ruang bagi pertumbuhan tunas (Paiti, 2017). Mekanisme pengolahan pati sagu dimulai dengan pemanenan batang sagu yang berumur 10 tahun atau setara dengan 7 ruas batang sagu. Batang-batang tersebut ditebang untuk dipotong menjadi ruas-ruas sepanjang $\pm 42 \mathrm{~cm}$ yang kemudian dikirimkan ke kilang dengan menggunakan alat transportasi air yang disebut Pompong (sampan) dengan cara diikat seperti balok. Tujuannya untuk diproses menjadi pati sagu di tempat pengolahan Kilang (Rifa, 2016). Kilang sagu milik rakyat menggunakan teknologi semi mekanis dan masih memanfaatkan sinar matahari untuk pengeringan (penjemuran) dan beberapa diantaranya sudah memanfaatkan mesin pengering sederhana dengan menggunakan ruyung (kulit batang sagu) sebagai bahan bakarnya.

Selain itu banyak aspek teknik belum ditangani secara sistematis dan tuntas serta penggunaan teknologi yang masih sangat sederhana. Teknologi yang digunakan umumnya secara manual tradisional dan sebagian kecil secara semi mekanis. Hal demikian menyebabkan masih banyak tepung sagu yang terbuang karena proses ekstraksi yang kurang efisien, sehingga produktivitas rendah serta mutu tepung sagu yang dihasilkan rendah (Purwanto, Rosnita, dan Yulida, 2017). Saat ini baru terdapat dua kilang sagu yang telah beroperasi dan memproses sagu secara semi modern. Disini peran pemerintah terutama pemerintah daerah Kabupaten Kepulauan Meranti sangat dibutuhkan, terutama melalui stakeholder dan instansi terkait. Sehingga visi dan misi untuk pengembangan tanaman sagu dalam rangka membangun industri daerah dapat diwujudkan secara simultan dan tepat sasaran.

\section{TINJAUAN PUSTAKA}

Strategi merupakan langkah-langkah yang berisikan program-program indikatif untuk mewujudkan visi dan misi. Satu strategi dapat terhubung dengan pencapaian satu sasaran. Dalam hal beberapa sasaran bersifat inherent dengan satu tema, satu strategi dapat dirumuskan untuk mencapai gabungan beberapa sasaran tersebut. Strategi dan arah kebijakan merupakan rumusan perencanaan komprehensif tentang bagaimana Pemerintah Daerah mencapai tujuan dan sasaran RPJMD dengan efektif dan efisien. Strategi harus dijadikan salah satu rujukan penting dalam perencanaan pembangunan daerah (strategy focussed management) (Sumber: kominfo.kotabogor.go.id n.d.). Gamage dan Pang, menjelaskan "Kebijakan terdiri dari pernyataan tentang sasaran dan satu atau lebih pedoman yang luas untuk mencapai sasaran tersebut sehingga dapat dicapai yang dilaksanakan bersama dan memberikan kerangka kerja bagi pelaksanaan program (Syafaruddin, 2008).

Komoditas sagu merupakan komoditas kearifan lokal dan memiliki nilai strategis untuk dikembangkan, sehingga diperlukan keberpihakan semua pihak dan kebijakan untuk menjadikan komoditas sagu sebagi komoditas unggulan yang perlu dan strategis untuk dikembangkan (Barrahima, 2017). Ada beberapa penelitian sejenis dalam pengembangan potensi sagu, misalnya penelitian yang dilakukan oleh Meilvis E. Tahitu, dkk, 2016 mengenai Strategi Pengembangan Kapasitas Pengelola Sagu Di Maluku Tengah Provinsi Maluku. Hasil penelitian menyebutkan bahwa, ada empat prioritas strategi untuk 
peningkatan pemanfaatan sagu, yaitu: (1) Penyiapan pengelola sagu untuk meningkatkan pemanfaatan sagu, (2) Penyiapan penyuluh/tenaga pendamping yang berkompeten di bidang pengelolaan sagu, (3) Penguatan kesadaran dan pengakuan masyarakat terhadap fungsi sosial dan budaya sagu untuk menjamin keberlanjutan usaha pemanfaatan sagu sebagai salah satu budaya Maluku, dan (4) Pemantapan koordinasi dan sinkronisasi kebijakan perencanaan program pengembangan sagu antar lembaga pemerintah dengan pihak-pihak terkait ( Meilvis. et al., 2016).

Penelitian berikutnya dilakukan oleh Muhammad Arlis Toselong, 2018 dengan judul Pengembangan Agribisnis Sagu Sebagai Pangan Lokal Berkelanjutan. Hasil penelitian menunjukkan bahwa potensi pengembangan agribisnis sagu di Kota Palopo sangat bergantung pada kondisi internal dan eksternal usaha tani, mulai dari hulu sampai hilir sebagai objek yang akan dikembangkan. Berdasarkan hasil evaluasi faktor internal diketahui bahwa kekuatan potensi pengembangan agribisnis sagu terletak pada kesesuaian iklim dan lahan, sedangkan yang menjadi kelemahan adalah industri rumah tangga pengolahan sagu belum berkembang. Sementara faktor eksternal menunjukkan bahwa peluangnya adalah permintaan konsumen terhadap produk sagu tinggi, sedangkan faktor dinilai sebagai ancaman adalah daya saing. Strategi perioritas yang berpengaruh terhadap pangan lokal berkelanjutan berdasarkan pelaku agribisnis berkriteria antar lain (1) produksi petani kontinyu; (2) pemasaran efisien; dan (3) peningkatan kualitas produk. Strategi perioritasnya sebagai berikut (1) bagi petani, yaitu adopsi teknologi untuk meningkatkan daya saing produk olahan sagu, membentuk kelompok tani, dan bantuan peralatan; (2) bagi pedagang pengumpul, yaitu bantuan peralatan dan memperluas jaringan kerja; (3) bagi pedagang pengecer, yaitu pengembangan; (4) bagi industri pengolahan sagu adalah peningkatan daya saing produk; dan (5) bagi pemerintah, yaitu peningkatan kapasitas petani melalui pendidikan dan pelatihan, memperluas jaringan pasar dan penyiapan penyuluh/tenaga pendamping yang berkompeten di bidang pengolahan sagu (Arlis Toselong, M., 2018).

Sejalan dengan penelitian sejenis tersebut, penelitian ini secara komprehensif juga menelusuri strategi dan arah kebijakan pengembangan sagu berbasis sentra Industri Kecil Menengah (IKM) yang ada di Kabupaten Kepulauan Meranti Provinsi Riau yang mana Kabupaten Kepulauan Meranti ini merupakan kawasan potensial terbesar penghasil Sagu di Indonesia yang perlu mendapatkan perhatian dari pemerintah pusat maupun pemerintah daerah.

\section{METODE}

Penelitian ini dilakukan di Kabupaten Kepulauan Meranti Provinsi Riau. Terutama pada bidang-bidang pemerintah yang memiliki tanggung jawab dalam Pengembangan Industri Kecil Menengah. Penelitian ini menggunakan pendekatan penelitian kualitatif yakni penelitian yang memusatkan perhatian kepada konsep-konsep yang timbul dari data, perhatian bukan kepada angka-angka yang diperoleh melalui pengukuran empiris namun terhadap konsep-konsep yang ada didalamnya. Suatu peristiwa empiris dapat menghasilkan suatu konsep (Suryabrata, 1998).

Jenis dan sumber data berupa data primer dan data sekunder. Data primer adalah diperoleh langsung dari informan penelitian dengan wawancara dengan tujuan untuk mengetahui secara langsung langkah dan kebijakan yang dibuat oleh Pemerintah dalam pengembangan sentra industri kecil menengah di kabupaten Kepulauan Meranti. Sementara yang kedua adalah data sekunder data yang diperoleh penulis dari dokumentasi, media massa atau informasi dari sumber lain yang dapat mendukung objek 
dan investigasi penelitian. Data yang telah didapat kemudian dinarasikan kemudian dianalisis secara deskriptif.

\section{HASIL DAN PEMBAHASAN}

Dalam undang-undang Republik Indonesia No.03 Tahun 2014 tentang Perindustrian, mengamanatkan Pemerintah dan Pemerintah Daerah melakukan percepatan penyebaran dan pemerataan pembangunan Industri ke seluruh wilayah Negara Kesatuan Republik Indonesia melalui Perwilayahan Industri. Perwilayahan industri yang dimaksud dilaksanakan melalui:

1. Pengembangan Wilayah Pusat Pertumbuhan Industri (WPPI);

2. Pengembangan Kawasan Peruntukan Industri (KPI);

3. Pembangunan Kawasan Industri (KI); dan

4. Pengembangan Sentra Industri Kecil dan Industri Menengah (Sentra IKM).

Untuk daerah-daerah yang tidak memungkinkan untuk berdirinya sebuah industri besar, maka industri dapat ditumbuhkan dengan mengembangkan industri kecil dan industri menengah melalui pengembangan Sentra Industri Kecil dan Industri Menengah. Upaya mengoptimalkan pelaksanaan pembangunan yang terdesentralisasi ini, maka pelaksanaan pembangunan disetiap daerah otonomi perlu dipersiapkan dengan penyusunan konsep pembangunan yang lebih matang yang sesuai dengan potensi, kendala dan kesempatan yang dimiliki oleh setiap daerah otonom tersebut. Di Dalam draft Kebijakan Rencana Tata Ruang Tata Wilayah Kabupaten Kepulauan Meranti salah satunya adalah kebijakan pelestarian dan pengembangan potensi sumber daya alam secara optimal sesuai daya dukung wilayah yakni diantaranya dengan mengembangkan kawasan pertambangan dan sumber daya alam lain dengan mempertimbangkan daya dukung lingkungan. Sentra industri kecil dan industri menengah adalah lokasi pemusatan kegiatan industri kecil dan industri menengah yang dilengkapi sarana dan prasarana penunjang yang dirancang berbasis pada pengembangan potensi sumber daya daerah, serta dikelola oleh badan pengelola.

Kebijakan pengembangan sagu berbasis Sentra Industri Kecil Menengah di Kabupaten Kepulauan Meranti dilakukan dengan Skenario Penataan Lokasi, Rencana penggunaan Lahan, dan melakukan pemetaan rencana sistem Jaringan Transportasi, Telekomunikasi, Listrik dan Air bersih.

\section{Skenario Penataan Lokasi}

Sebagaimana diketahui pembangunan pada dasarnya bertujuan untuk meningkatkan kesejahteraan masyarakat di segala bidang yang menyangkut kehidupan manusia, begitu pula dengan rencana pembangunan sentra IKM sagu ini, diharapkan dapat meningkatkan kesejahteraan masyarakat. Pembangunan merupakan proses perubahan yang terus menerus, yang merupakan kemajuan dan perbaikan mengarah pada suatu tujuan yang ingin dicapai. Perubahan dalam pembangunan sentra industri akan menimbulkan berkembangnya masyarakat yang semakin kompleks.

Perubahan sosial dirasakan di semua kegiatan kehidupan, baik sebagai dampak positif maupun negatif. Dampak dari orientasi pembangunan pada pertumbuhan ekonomi dengan mengembangkan industri sebagai basis pertumbuhan ekonomi, biasanya akan dirasakan dampak negatif terhadap lingkungan dan ketersediaan sumber daya alam. Disisi legalitas, rencana tersebut seyogyanya sudah mengakomodir berbagai aspek, baik kepemilikan maupun tata ruang, paling tidak rencana lokasi sentra industri sudah terakomodir dalam Rencana Tata Ruang Kabupaten setempat. 
Aspek legalitas tata ruang menjadi sangat penting mengingat jika lokasi rencana sentra industri tidak sesuai dengan rencana tata ruang, maka dokumen ini tidak dapat diproses lebih lanjut sesuai dengan ketentuan pasal 4 ayat (3) Peraturan Pemerintah Nomor 27 Tahun 2012. (Lamp. Permen LH No. 16 Tahun 2012). Rencana lokasi pengembangan dan pembangunan Sentra Industri Kecil dan Industri menengah berbahan dasar sagu bertempat di Desa Sungai Tohor, Kecamatan Tebing Tinggi Timur, Kabupaten Kepulauan Meranti. Lokasi ini dipilih sebagai lokasi sentra dikarenakan lokasi ini berada di tengah-tengah jalur perlintasan kanal Sungai Tohor menuju laut dan berada dalam lingkungan perkebunan sagu rakyat. Di lokasi ini sepanjang sungai tohor terdapat beberapa lokasi pengolahan pasca panen yang mengekstraksi empulur dari batang-batang sagu yang diambil dari perkebunan yang berada di Desa Sungai Tohor dan sekitarnya.

Untuk mencapai ke lokasi dari Ibu Kota Kabupaten Kepulauan Meranti, Selat Panjang, saat ini harus mengarungi selat sejauh $\pm 32 \mathrm{KM}$ (belum ada akses melalui darat), dengan menggunakan speed boat sewaan selama kisaran 1 (satu) jam ke Pelabuhan Desa Sei Tohor, sedangkan untuk sampai ke lokasi sentra harus menggunakan sepeda motor tersedia jalan lingkungan dengan lebar kisaran 2 meter dengan jarak ke lokasi sentra kisaran $2 \mathrm{Km}$. Sehingga sekilas akan banyak effort yang harus disediakan lebih dahulu guna mendukung sentra industri kecil ini, mulai dari penyediaan infrastruktur jalan, pelabuhan, trayek angkutan (darat dan laut), dan infrastruktur penunjang lain.

Selain itu, pada tahap perencanaan konsep dan strategi pembangunan kawasan industri beserta infrastruktur dan fasilitas penunjangnya wajib memegang prinsip pembangunan yang berkelanjutan, dimana industri yang dibangun atau dikembangkan merupakan industri ramah lingkungan yang dapat meminimalisir dampak negatif terhadap lingkungan dan sosial, khususnya permasalahan yang krusial dari adanya industri adalah polusi (pencemaran air, tanah, udara, suara) sehingga membutuhkan peralatan instalasi yang cermat, tepat dan efisien guna meminimalisir kadar pencemaran yang timbul.

Selain itu diperlukannya pemantauan dan pengawasan secara intensif maupun berkala terhadap buangan limbah (cair, padat atau bahkan B3) serta emisi (bahan bakar) agar hasil buangan akhir menuju alam dapat memenuhi baku mutu lingkungan hidup (baku mutu air, air limbah, air laut, udara ambien, emisi, dsb) sebagaimana yang tertuang dalam UU No. 32 Tahun 2009 tentang Perlindungan dan Pengelolaan Lingkungan Hidup.

Lokasi Pengembangan Sentra IKM Desa Sungai Tohor memiliki jarak $\pm 1 \mathrm{Km}$ dari permukiman penduduk Desa Sungai Tohor. Dengan jarak tersebut sangat menguntungkan bagi tenaga kerja khususnya yang berasal dari penduduk setempat dengan jarak yang dekat menuju tempat kerja dan tidak membutuhkan biaya perjalanan yang tinggi, namun disisi lain memungkinkan adanya dampak atau pengaruh negatif dari kegiatan industri, khususnya berdampak pada lingkungan (dampak risiko lingkungan hidup) dan sosial penduduk sekitar (kesehatan, konflik sosial, dll). Dengan demikian perlu adaya sosialisasi dan komunikasi berbagai arah antara pemerintah, pelaku usaha/industri dan penduduk sekitar untuk bersama-sama berkomitmen terkait antisipasi penanggulangan dampak negatif yang kemungkinan akan terjadi akibat kegiatan industri serta tindakan jaminan yang akan diberikan kepada lingkungan dan penduduk yang terkena dampak negatif tersebut. Sehingga mampu bersaing di tengah perkembangan peradaban Revolusi Industri 4.0 guna tetap survive dalam menjalankan tugas pokok dan fungsinya dengan lebih efesien 
dan efektif sebagai responsit terhadap meningkatnya tuntutan akuntabilitas dan transparasi publik(Hartati, Syamsuadi, dan Elvitaria, 2020).

Dengan standar ideal berjarak 10-20 Km dari Pusat Kota, maka Lokasi Pengembangan Sentra IKM di Desa Sungai Tohor yang dihitung berdasarkan waktu memliki jarak tempuh 1 jam melalui Selat (menggunakan speed boat) atau $\pm 32 \mathrm{Km}$ dari Pusat Perkotaan Selatpanjang. Sedangkan Desa Sungai Tohor sebagai Ibukota Kecamatan Tebing Tinggi Timur (Pulau Tebing) memiliki jarak \pm 31,5 Km dari Ibukota Kabupaten yaitu Kota Selatpanjang yang dihitung berdasarkan garis lurus.

Sebenarnya jarak lokasi sentra ke pusat kota tidak terlalu jauh jika ditunjang dengan sarana dan prasarana transportasi yang memadai, akan tetapi mengingat lokasi sentra belum ditunjang dengan infrastruktur tersebut, maka hal ini berpotensi akan menjadi kendala kedepannya, terutama berkaitan dengan pendistribusian dan pemasaran produk sentra. Posisi lokasi saat ini menjadi di bawah standar ideal, namun apabila didukung dengan pembangunan infrastruktur dan fasilias penunjang lainnya yang memadai, maka jarak akan menjadi tidak berarti lagi. Tujuan pokok pertimbangan terhadap permukiman adalah memberikan kemudahan pencapaian tenaga kerja, mengurangi kepadatan lalu lintas dan mengurangi dampak polutan yang dapat membahayakan bagi kesehatan masyarakat serta menghindari penurunan kualitas lingkungan dengan tumbuhnya permukiman kumuh yang biasanya merupakan permukiman pekerja/tenaga kerja. Berdasarkan pertimbangan tersebut standar idealnya jarak terhadap permukiman adalah minimal 2 (dua) Km dari lokasi kegiatan industri.

Jaringan transportasi darat bagi kegiatan industri sebagai sistem pergerakan yang mempermudah mobilitas pergerakan orang dan barang serta aksesibilitas logistik yaitu jaringan jalan. Ketersediaan jaringan jalan harus memperhitungkan kapasitas dan jumlah kendaraan yang akan melalui jalan tersebut, sehingga dapat diantisipasi kemungkinan terjadinya kerusakan jalan. Kawasan industri sebaiknya terlayani oleh jaringan jalan arteri primer untuk pergerakan lalu lintas kegiatan industri. Akan tetapi, mungkin ada pertimbangan lain dalam menentukan lokasi, selain dari ketersediaan lahan, juga lokasi ini berada di sekitar sumber bahan baku, mengingat Kecamatan Tebing Tinggi Timur sendiri merupakan penghasil sagu terbanyak di Kabupaten Kepulauan Meranti dengan akses distribusi melalui Sungai Tohor langsung ke selat.

Pertimbangan jarak ke pusat kota dilakukan dalam rangka memperoleh kemudahan fasilitas pelayanan baik dari sisi infrastruktur, sarana penunjang maupun sisi pemasaran. Selain itu dengan adanya keterdekatan terhadap pusat kota yang memiliki infrastruktur dan fasilitas penunjang yang sudah ada/terbangun dapat dimanfaatkan untuk mendukung pengembangan sentra IKM, hal ini sangat terkait dengan kebutuhan supply listrik dan air minum serta ketersediaan fasilitas keuangan (perbankan) dan kantor pelayanan pemerintahan yang memberikan jasa pelayanan bagi kegiatan IKM yang pada umumnya berlokasi di Pusat Kota. Dengan demikian dalam pengembangan Sentra IKM tidak harus membangun seluruh infrastruktur dari tahap awal, selain itu dengan memanfaatkan infrastruktur dan fasilitas pusat kota akan memberikan efek keterpaduan pembangunan dan pemerataan pelayanan pusat kota. 


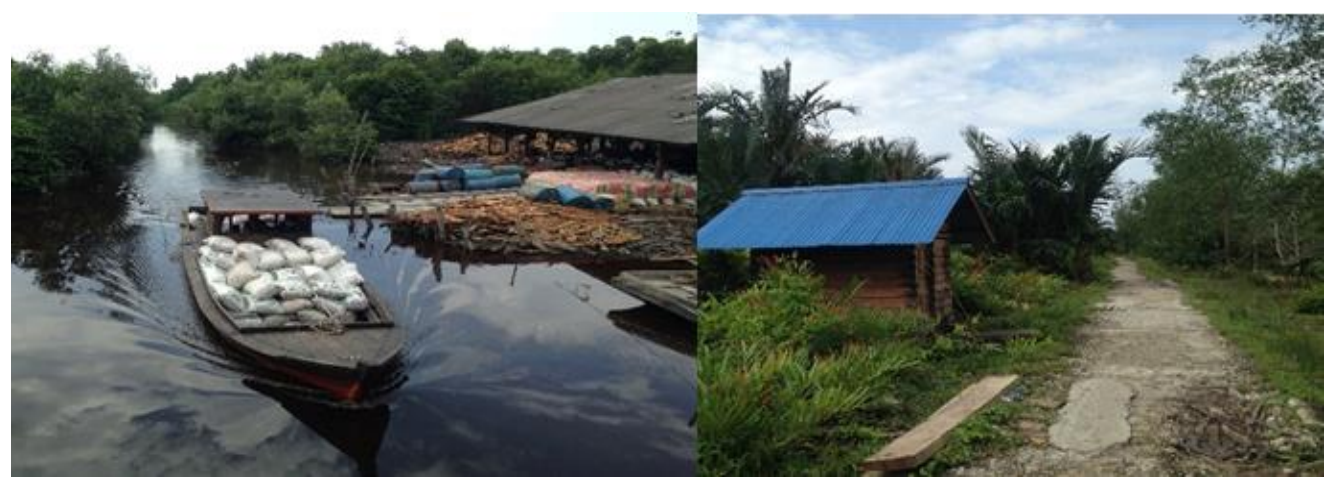

Gambar 1. Jalur transportasi pada lokasi Industri

Air menjadi transportasi utama pada lokasi IKM dan ketersediaan jalan kebun sebagai jalan tani. Lokasi pengembangan sentra IKM Desa Sungai Tohor sendiri pada saat ini hanya dapat diakses melalui jalur air atau selat sehingga transportasi air dengan sistem jaringan jalan kanal sangat penting disediakan dan didesain tepat sebagai sistem transportasi utama. Sedangkan untuk jaringan jalan (darat), Desa Sungai Tohor sendiri dalam RTRW dilalui oleh jaringan jalan Kolektor Primer (status Jalan Provinsi) ruas jalan Lukun-Tanjung Sari. Sebagai sistem eksternal, ruas jalan tersebut dapat dijadikan sebagai akses utama menuju Desa Sungai Tohor dan pengembangan node akses internal menuju lokasi sentra. Dengan mempertimbangkan lahan berupa gambut atau rawa, maka penyediaan jaringan jalan dapat disediakan dengan struktur jembatan (berada di atas muka air tertinggi) dan struktur jalan di atas lahan basah dengan dilakukannya penimbunan tanah.

\section{Rencana Penggunaan Lahan}

Ketersediaan lahan pengembangan Sentra IKM berdasarkan Kemenperin adalah dengan menyediakan lahan untuk pembangunan sentra IKM (minimal $5 \mathrm{Ha}$ ) dengan status clear and clean, begitu juga dengan standar alokasi peruntukan lahan kawasan industri khusus industri kecil dan menengah minimal 5 Ha (PP No. 142 Tahun 2015 tentang Kawasan Industri dan Permen Perind No. 40 Tahun 2016 tentang Pedoman Teknis Pembangunan Kawasan Industri).

Berdasarkan hal tersebut, maka pemerintah Kabupaten Kepulauan Meranti menyiapkan lahan seluas $\pm 29.915 \mathrm{~m}^{2}$ atau seluas 2,99 Ha yang berada di sebelah Utara Sungai Tohor. Berdasarkan luas lahan yang akan disiapkan tersebut belum memenuhi kebutuhan ideal luas lahan pengembangan IKM, oleh karena itu dibutuhkan penambahan lahan alternatif yang direncanakan berada di bagian Selatan Sungai Tohor seluas $\pm 23.598 \mathrm{~m}^{2}$ (2,36 Ha) sehingga luas lahan yang direncanakan total 5,35 Ha. Sebagai antisipasi permintaan lahan pengembangan jangka panjang, maka alokasi luas lahan sudah memenuhi batas minimal. Ketersediaan lahan yang melebihi batas minimal dipersiapkan untuk kebutuhan lahan di luar kegiatan sekor industri, seperti kebutuhan perumahan tenaga kerja dan fasilitas pendukungnya.

Terkait dengan kesiapan lahan akan tergantung dengan aspek legalitas lahan (status kepemilikan lahan clear and clean). Untuk status kepemilikan lahannya sendiri, lahan yang akan direncanakan sebagai sentra pengembangan IKM merupakan Tanah Hibah BUMDES untuk Lokasi 1 sedangkan untuk lokasi 2 belum mendapatkan kepastian dan konfirmasi dari Pihak BPN dan Disperidag setempat. Persyaratan lahan yang bersifat clear and clean menuntut pemerintah untuk melakukan sertifikasi terhadap lahan yang akan digunakan untuk menjamin kesiapan lahan dan tidak dalam sengeketa tanah/lahan. 
Pemahaman terhadap standar teknis pola penggunaan lahan Sentra IKM diperlukan dalam rangka memilih lokasi yang tepat bagi rencana lokasi Sentra IKM maupun dalam menilai apakah rencana pengembangan sentra IKM yang memenuhi berbagai prasyarat teknis, sehingga dapat menghindari terjadinya permasalahan teknis dan lingkungan. Ketentuan tentang pemanfaatan tanah untuk bangunan seperti Koefisien Dasar Bangunan (KDB/BCR), Koefisien Lantai Bangunan/KLB, Garis Sempadan Bangunan/GSB diatur sesuai dengan ketentuan Pemerintah Daerah yang berlaku. Secara lengkap pola penggunaan lahan suatu sentra industri dapat mengacu pada pedoman Teknis Pembangunan Kawasan Industri dapat dilihat pada berikut ini:

Tabel 2. Alokasi Pola Penggunaan Lahan Sentra IKM

\begin{tabular}{|c|c|c|c|}
\hline No & $\begin{array}{c}\text { Jenis } \\
\text { Penggunaan } \\
\end{array}$ & $\begin{array}{c}\text { Struktur } \\
\text { Penggunaan (\%) }\end{array}$ & Keterangan \\
\hline 1 & Kapling Industri & Maksimal $70 \%$ & $\begin{array}{l}\text { Setiap kapling harus mengikuti ketentuan KDB } \\
(60: 40) \text { atau Ketetuan Peraturan Perda Setempat }\end{array}$ \\
\hline 2 & Jalan dan Saluran & $8-10 \%$ & $\begin{array}{l}\text { - Untuk tercapainya aksessibilitas di mana ada jalan } \\
\text { primer dan jalan sekunder (pelayanan) } \\
\text { - Tekanan gandar primer sebaiknya minimal } 8 \text { ton } \\
\text { dan sekunder minimal } 5 \text { ton } \\
\text { - Perkerasan jalan minimal } 7 \mathrm{~m}^{2} \\
\text { - Saluran drainase } \\
\text { - Saluran Limbah } \\
\text { - Saluran Air Minum }\end{array}$ \\
\hline 3 & $\begin{array}{l}\text { Ruang Terbuka } \\
\text { Hijau }\end{array}$ & Minimal 10\% & $\begin{array}{l}\text { Dapat berupa jalur hijau (green belt), taman dan } \\
\text { perimeter }\end{array}$ \\
\hline 4 & $\begin{array}{l}\text { Infrastruktur } \\
\text { dasar lainnya, } \\
\text { infrastrukur dan } \\
\text { fasilitas penunjang }\end{array}$ & $8-10 \%$ & $\begin{array}{l}\text { Dapat berupa Kantor Pengelola dan UPT, Parkir, } \\
\text { Tempat Ibadah, Penerangan Jalan, Pemadam } \\
\text { Kebakaran (Hydrant), Pos Keamanan, IPAL, WWTP, } \\
\text { Ruang Genset, Ruang Sarana Komunikasi, Ruang } \\
\text { Showroom, dsb }\end{array}$ \\
\hline
\end{tabular}

Pembagian kaveling sentra IKM akan terbagi berdasarkan penataan tapak sistem zoning dalam perencanaan blok. Berdasarkan tabel jenis kegiatan di atas dapat diperkirakan tata letak setiap jenis kegiatan, namun untuk beberapa kegiatan nampaknya perlu ada pentahapan. Pentahapan ini didasarkan kepada prospek yang berkembang. Berdasarkan hasil pemantauan di lapangan, masyarakat sekitar sudah terbiasa untuk mengolah sagu basah, sehingga yang menjadi prioritas tahun ke 1 adalah pengolahan sagu basah, sedangkan untuk produksi dan pengolahan sagu kering di lakukan tahun ke-2, hal ini idealnya setelah berjalannya pusat penelitian dan pengembangan di tahun ke-2, artinya pembangunan untuk sagu kering setelah ada rekomendasi dari bagian litbang, sehingga produk-produk olahan sagu kering nantinya memang produk yang sudah siap diterima pasar, baik dalam negeri maupun luar negeri. Sedangkan untuk perkiraan IKM yang akan ditampung di Sentra IKM berdasar Permenperin paling tidak harus ada 10 (sepuluh) IKM. Seperti yang telah dijelaskan sebelumnya bahwa di sekitar Sentra IKM sebenarnya sudah ada 14 kilang sagu basah IKM yang dapat masuk kedalam Sentra IKM, akan tetapi berdasarkan hasil informasi dari Dinas Perindustrian bahwa yang diprioritaskan saat ini adalah pembuatan tepung sagu kering dimana 14 kilang tersebut mensupport bahan bakunya yang tidak lain adalah berupa tepung sagu basah yang selama ini mereka jual ke Malaysia.

Apabila konsepnya seperti tersebut di atas, maka 14 kilang tersebut untuk saat ini tidak ada yang berada di dalam Sentra IKM, sehingga yang berada di sentra adalah produksi tepung sagu kering, macam-macam pengolahan sagu basah dan sagu kering, pengolahan limbah sagu, serta pengemasan. ini dilakukan untuk efisiensi dan 
efektifitas dalam penyediaan infrastruktur dan utilitasnya. Untuk menghindari dampak polutan antar kegiatan produksi/aktivitas maka pembagian kaveling menjadi 4 (empat) kaveling, yaitu:

a. Kapling usaha/produksi tepung (ruang produksi, gudang bahan baku, gudang produk, areal bongkar muat, parkir karyawan);

b. apling usaha/produksi pengolahan makanan dan minuman serta rumah kemasan;

c. Kapling fasilitas penunjang (kantor pengelola, kantor upt, kantin, gedung Promosi/Showroom/Etalase Produk, sarana ibadah, parkir karyawan dan Pengunjung, RTH Taman, Balai Pembinaan dan Pelatihan, dsb).

d. Kapling Instalasi (IPAL/WWTP, Gardu Induk, pengolahan energi alternatif terbarukan, instalasi pengolahan air (IPA), TPST, menara telekomunikasi).

\section{Pemetaan Rencana Sistem Jaringan Transportasi, Telekomunikasi, Listrik dan Air Bersih}

Sistem jaringan transportasi pendukung kegiatan sentra industri dibagi di Kabupaten Kepulauan Meranti ini menjadi 2 yakni sistem transportasi yakni jaringan jalan dan sistem jaringan laut. Sistem jaringan jalan merupakan satu kesatuan jaringan jalan yang terdiri dari sistem jaringan jalan primer dan sistem jaringan jalan sekunder yang terjalin dalam hubungan hirarki. Sistem jaringan jalan disusun dengan mengacu pada rencana tata ruang wilayah dan dengan memperhatikan keterhubungan antar kawasan dan atau dalam kawasan perkotaan, dan kawasan perdesaan.

Sistem jaringan jalan primer disusun berdasarkan rencana tata ruang dan pelayanan distribusi barang dan jasa untuk pengembangan semua wilayah di tingkat nasional, dengan menghubungkan semua simpul jasa distribusi yang berwujud pusatpusat kegiatan dengan Menghubungkan secara menerus pusat kegiatan nasional, pusat kegiatan wilayah, pusat kegiatan lokal sampai ke pusat kegiatan lingkungan; dan menghubungkan antarpusat kegiatan nasional. Pada tahun 2015, permukaan jalan di Kabupaten Kepulauan Meranti berupa kerikil (38 persen), aspal (28 persen), beton (26 persen) dan sisanya berupa tanah. Tahun 2014, jumlah penumpang yang turun dari angkutan dalam negeri sebanyak 311.171 dan penumpang naik sejumlah 302.579 . Jumlah penumpang turun dari angkutan luar negeri sejumlah 12.512 dan penumpang naik sejumlah 10.479 .

Hal ini juga dilandasi dari masuknya era revolusi industri 4.0 yang menuntut pemanfaatan teknologi informasi dan komunikasi menjadi keharusan dalam mengikuti perkembangan (Alfiyah, 2019).

Tabel 3. Pelabuhan-Pelabuhan Utama di Kabupaten Kepulauan Meranti

\begin{tabular}{|c|c|c|c|c|c|}
\hline No & $\begin{array}{c}\text { Nama } \\
\text { Pelabuhan }\end{array}$ & Wilayah Pelayanan & Kegiatan Yang dilayani & $\begin{array}{c}\text { Arahan } \\
\text { Fungsi dan } \\
\text { Hierarki } \\
\text { Pelabuhan }\end{array}$ & Realisasi \\
\hline 1 & $\begin{array}{l}\text { Selat } \\
\text { Panjang }\end{array}$ & $\begin{array}{ll}\text { - } & \text { Tebing Tinggi. } \\
\text { - } & \text { Tebing Tinggi } \\
& \text { Barat, } \\
\text { - } & \text { Rangsang } \\
\text { - } & \text { Rangsang Barat } \\
\text { - } & \text { Merbau. }\end{array}$ & $\begin{array}{ll}\text { a. } & \text { Komoditi pertanian } \\
\text { b. Komoditi agroindustri } \\
\text { c. Komoditi perdagangan } \\
\text { d. Kebutuhan sehari-hari } \\
\text { e. Penumpang orang } \\
\text { f. Interchange timur }\end{array}$ & $\begin{array}{c}\text { Pengumpan } \\
\text { Regional }\end{array}$ & $\begin{array}{c}\text { Sudah } \\
\text { Terbangun }\end{array}$ \\
\hline 2 & $\begin{array}{l}\text { Tanjung } \\
\text { Samak }\end{array}$ & - Rangsang & $\begin{array}{l}\text { a. Komoditi Pertanian } \\
\text { b. Komoditi Agroindustri } \\
\text { c. Penumpang orang } \\
\text { d. Exit and Entry Point ke } \\
\text { Batu Pahat }\end{array}$ & $\begin{array}{c}\text { Pengumpan } \\
\text { Regional }\end{array}$ & $\begin{array}{c}\text { Sudah } \\
\text { Terbangun }\end{array}$ \\
\hline
\end{tabular}




\begin{tabular}{|c|c|c|c|c|c|}
\hline No & $\begin{array}{l}\text { Nama } \\
\text { Pelabuhan }\end{array}$ & Wilayah Pelayanan & Kegiatan Yang dilayani & $\begin{array}{c}\text { Arahan } \\
\text { Fungsi dan } \\
\text { Hierarki } \\
\text { Pelabuhan } \\
\end{array}$ & Realisasi \\
\hline 3 & $\begin{array}{l}\text { Teluk } \\
\text { Belitung }\end{array}$ & - Merbau & $\begin{array}{l}\text { a. Komoditi pertanian } \\
\text { b. Penumpang orang } \\
\text { c. Exit and entry point ke } \\
\text { Batu Pahat }\end{array}$ & $\begin{array}{l}\text { Pengumpan } \\
\text { Lokal }\end{array}$ & $\begin{array}{l}\text { Sudah } \\
\text { Terbangun }\end{array}$ \\
\hline 4 & Bandul & - Merbau & $\begin{array}{l}\text { a. Komoditi pertanian } \\
\text { b. Penumpang orang }\end{array}$ & $\begin{array}{l}\text { Pengumpan } \\
\text { Lokal }\end{array}$ & $\begin{array}{c}\text { Sudah } \\
\text { Terbangun }\end{array}$ \\
\hline 5 & $\begin{array}{l}\text { Tanjung } \\
\text { Kedabu }\end{array}$ & - Rangsang & Komoditi pertanian & $\begin{array}{l}\text { Pengumpan } \\
\text { Lokal }\end{array}$ & $\begin{array}{c}\text { Sudah } \\
\text { Terbangun }\end{array}$ \\
\hline
\end{tabular}

Sumber: RTRW Kabupaten Kepulauan Meranti 2011-2031

Prasarana perhubungan air yang terdiri dari prasarana perhubungan laut dan sungai, memiliki peranan yang sangat penting dalam mendukung transportasi wilayah kepulauan. Prasarana perhubungan laut dan sungai di Kabupaten Kepulauan Meranti didukung oleh: pelabuhan-pelabuhan ibukota kecamatan, pelabuhan-pelabuhan pedesaan pesisir serta pelabuhan-pelabuhan internasional. Perkembangan prasarana pelabuhan utama di Kabupaten Kepulauan Meranti adalah 5 pelabuhan yang menjadi aset Kabupaten Kepulauan Meranti. Selain pelabuhan, terdapat juga dermaga penyebrangan yang merupakan kepanjangan dari jaringan prasarana jalan yang terputus akibat adanya sungai atau selat.

Tabel 4. Dermaga Penyeberangan Utama Kabupaten Kepulauan Meranti

\begin{tabular}{|c|c|c|c|c|}
\hline No. & Lokasi Dermaga & Fungsi & Jenis & Realisasi \\
\hline 1. & $\begin{array}{l}\text { Desa Ketam Putih - } \\
\text { Desa Tanjung Padang }\end{array}$ & $\begin{array}{l}\text { Menghubungkan Pulau Bengkalis } \\
\text { dengan Pulau Padang }\end{array}$ & Perahu Motor & $\begin{array}{l}\text { Sudah } \\
\text { Terbangun }\end{array}$ \\
\hline 2. & $\begin{array}{l}\text { Desa Merani Bunting } \\
\text { - Desa tanjung } \\
\text { Peranap }\end{array}$ & $\begin{array}{l}\text { Menghubungkan Pulau Bengkalis } \\
\text { dengan Pulau Padang }\end{array}$ & Perahu Motor & $\begin{array}{l}\text { Sudah } \\
\text { Terbangun }\end{array}$ \\
\hline 3. & $\begin{array}{l}\text { Desa Insit - Desa } \\
\text { Bantar }\end{array}$ & $\begin{array}{l}\text { Menghubungkan Pulau Tebing Tinggi } \\
\text { dengan Pulau Rangsang }\end{array}$ & Perahu Motor & $\begin{array}{l}\text { Sudah } \\
\text { Terbangun }\end{array}$ \\
\hline 4. & $\begin{array}{l}\text { Desa Mengkikit-Desa } \\
\text { Mengkapan Buton }\end{array}$ & $\begin{array}{l}\text { Menghubungkan Kecamatan Tebing } \\
\text { Tinggi Barat dengan Kabupaten Siak }\end{array}$ & $\begin{array}{l}\text { RORO } \\
\text { (blm. Berjalan) }\end{array}$ & $\begin{array}{l}\text { Sudah } \\
\text { Terbangun }\end{array}$ \\
\hline
\end{tabular}

Sumber: RTRW Kabupaten Kepu lauan Meranti 2011-2031

Pada saat ini pelayanan jasa pos telah menjangkau seluruh wilayah Kabupaten, dimana setiap ibukota kecamatan telah memiliki Kantor Pos. Selain adanya Kantor Pos yang melayani jasa pos dan jasa pengiriman paket atau barang, pada beberapa ibukota kecamatan sudah terdapat jasa pengiriman paket dan barang yang dilakukan oleh swasta seperti TIKI JNE, DHL, dan lain-lain. Di bidang pelayanan jasa telekomunikasi, pengembangannya dilakukan oleh PT. Telkom, PT. Indosat, PT. Telkomsel, PT. Satelindo, serta beberapa provider lainnya, telah mampu menjangkau seluruh wilayah Kabupaten, baik dengan pesawat telepon biasa maupun telepon seluler. Adapun jasa yang diberikan adalah jasa telepon, faximile serta internet.

Untuk kebutuhan telepon seluler, gerai-gerai yang melayani kebutuhan telepon seluler sudah banyak tersebar di seluruh wilayah Kabupaten, sehingga hal ini sangat memudahkan untuk melalukan aktifitas kegiatan telekomunikasi di masyarakat. Karena perkembangan ekonomi yang terus berkembang, serta kemampuan PLN dalam menyediakan listrik masih belum dapat menambah kuantitas listrik, maka pemerataan kebutuhan akan tenaga listrik di wilayah Kabupaten Bengkalis belum berjalan sesuai 
dengan rencana. Biaya tinggi dalam pengembangan listrik pedesaan yang disebabkan posisi desa yang berjauhan membuat belum meratanya kebutuhan listrik.

Di Kota Selat Penjang sebagai ibukota Kabupaten Kepulauan Meranti, masih terjadi pemadaman secara bergilir. Hal ini terjadi karena kemampuan produksi listrik lebih kecil dari kebutuhan kota yang berkembang pesat. Berkembangnya pembangunan ruko serta pembangunan fasilitas dan utilitas baru membuat kebutuhan akan tenaga listrik semakin meningkat.

Tabel 5. Sebaran Lokasi dan Ketersediaan Prasarana Listrik Kabupaten Kepulauan Meranti 2009

\begin{tabular}{|c|c|c|c|c|c|c|c|c|c|}
\hline \multirow[b]{2}{*}{ No } & \multirow[b]{2}{*}{ Lokasi } & \multirow[b]{2}{*}{$\begin{array}{c}\text { Jumlah } \\
\text { Unit }\end{array}$} & \multicolumn{3}{|c|}{ Daya } & \multicolumn{2}{|c|}{ Realisasi } & \multicolumn{2}{|c|}{ Daftar Tunggu } \\
\hline & & & $\begin{array}{c}\text { Terpas } \\
\text { ang }\end{array}$ & Mampu & Operasi & $\begin{array}{c}\text { Beban } \\
\text { Real } \\
(\mathrm{KW})\end{array}$ & $\begin{array}{l}\text { Pemad } \\
\text { aman } \\
(\mathrm{KW})\end{array}$ & $\begin{array}{c}\text { Jumlah } \\
\text { Calon } \\
\text { Pelangga } \\
\text { n }\end{array}$ & $\begin{array}{c}\text { Beban } \\
\text { (KW) }\end{array}$ \\
\hline 1. & Selat Panjang & 11 & 14.350 & 5.500 & 5.310 & 6.500 & 1.650 & 4.075 & 4.101 \\
\hline 2. & Teluk Belitung & 3 & 1.200 & 700 & 460 & 460 & - & 81 & 100 \\
\hline 3. & Tanjung Samak & 6 & 860 & 520 & 405 & 405 & - & 50 & 80 \\
\hline 4. & Bandul & 2 & 200 & 180 & 130 & 170 & 50 & 53 & 68 \\
\hline 5. & Teluk Buntal & 1 & 100 & 80 & 64 & 64 & - & - & - \\
\hline 6. & Teluk Ketapang & 2 & 200 & 90 & 68 & 68 & - & 56 & 58 \\
\hline 7. & Lemang & 2 & 800 & 590 & 440 & 440 & - & 523 & 1.112 \\
\hline & Jumlah Total & 27 & 17.620 & 7.660 & 6.877 & 8.043 & 1.700 & 4.838 & 5.519 \\
\hline
\end{tabular}

Sesuai dengan program pemerintah pusat tentang ketenaga listrikan, maka Kabupaten Kepulauan Meranti merupakan salah satu Kabupaten yang mendapat program tentang pengembangan tenaga listrik, yaitu dengan akan dibangunnya Pembangkit Listrik Tenaga Uap (batubara) di Kecamatan Tebing Tinggi Barat. Kedepan perlu dikembangkan suatu teknologi yang menghasilkan tenaga listrik seperti tenaga surya, tenaga mini hydro terutama untuk desa-desa terpencil serta pengembangan dan peningkatan jaringan listrik dengan pelayanan yang maksimal. Kebijakan pemerintah di bidang kelistrikan ditunjukkan untuk meningkatkan kesejahteraan masyarakat. Untuk mencapai sasaran tersebut diupayakan peningkatan daya terpasang pembangkit tenaga listrik serta perluasan jaringan distribusi agar tersedia tenaga listrik dalam jumlah yang cukup dengan pelayanan yang baik.

Tabel 6. Banyaknya Produksi Tenaga Listrik dirinci Menurut Jenis Pelanggan di Kab. Kepulauan Meranti (Kwh) Tahun 2015

\begin{tabular}{|c|c|c|c|}
\hline \multicolumn{2}{|r|}{ Jenis Pelanggan } & $\begin{array}{l}\text { Jumlah } \\
\text { Pelanggan }\end{array}$ & $\begin{array}{l}\text { Penggunaan } \\
\text { (KWH) }\end{array}$ \\
\hline 1 & Pabrik / Industri & 11 & 72.494 \\
\hline 2 & Bisnis & 2.257 & 1.207 .526 \\
\hline 3 & Kantor Pemerintahan & 222 & 274.873 \\
\hline 4 & $\begin{array}{l}\text { Sekolah, Rumah Sakit, Tempat Ibadah/Fasilitas Sosial } \\
\text { Lainnya }\end{array}$ & 563 & 209.569 \\
\hline 5 & Rumah Tangga & 25.315 & 4.037 .739 \\
\hline 6 & Penerangan Jalan & 59 & 124.328 \\
\hline 7 & Dipakai Sendiri & 11 & 8.306 \\
\hline 8 & Hilang & - & - \\
\hline \multicolumn{2}{|r|}{ Jumlah Total } & 28.438 & 5.934 .835 \\
\hline
\end{tabular}

Sumber: Kabupaten Kepulauan Meranti Dalam Angka 2016 
Prasarana air bersih di Kabupaten Kepulauan Meranti dikelola oleh PDAM dimana pada saat ini untuk keperluan air bersih penduduk yang tersedia sistem pengolahannya tinggal di 2 kecamatan, yaitu : Selat Panjang (Kecamatan Tebing Tinggi) dan Tajung Samak (Kecamatan Rangsang). Sedangkan tempat-tempat lainnya masih mengandalkan swadaya dalam bentuk sumur bor atau sumur gali. Sedangkan untuk kebutuhan mandi dan cuci masyarakat mengandalkan pada penampungan air hujan dan air sungai/kali serta air gambut. Kedepan, kebutuhan akan air bersih akan meningkat seiiring dengan bertambahnya penduduk, kegiatan perekonomian yang meningkat, serta pengembangan kawasan industri.

Tabel7. Kapasitas Produksi Air Bersih dan Jumlah Pelanggan di Kabupaten Kepulauan Meranti

\begin{tabular}{|c|c|c|c|c|}
\hline \multirow{2}{*}{ No } & \multirow{2}{*}{ Rincian } & \multicolumn{2}{|c|}{ Cabang PDAM } & \multirow{2}{*}{ Jumlah } \\
\hline & & $\begin{array}{c}\text { Selat } \\
\text { Panjang }\end{array}$ & $\begin{array}{c}\text { Tanjung } \\
\text { Samak }\end{array}$ & \\
\hline 1 & Volume Penyimpanan air $\left(\mathrm{m}^{3}\right)$ & 1.200 & 500 & 7.950 \\
\hline 2 & $\begin{array}{l}\text { Kapasitas terpasang Produksi air bersih } \\
\text { (liter/detik) }\end{array}$ & 40 & 20 & 260 \\
\hline 3 & Jumlah Pelanggan & 73 & 435 & 10.442 \\
\hline 4 & Volume Air bersih tersalurkan $\left(\mathrm{m}^{3}\right)$ & 106.874 & 12.725 & 2.270 .289 \\
\hline 5 & Jumlah kelurahan/desa yang dialiri air bersih & 6 & 1 & 30 \\
\hline 6 & Kebocoran Jaringan Distribusi (\%) & 29 & 15 & 20 \\
\hline
\end{tabular}

Sumber: Kabupaten Kepulauan Meranti Dalam Angka 2016

Pada tahun 2016, Pemerintah Daerah Kabupaten Kepulauan Meranti telah membangun SPAM IPA (Sistem Penyediaan Air Minum- Instalasi Pengolahan Air) dengan kapasitas 5 liter/detik di Desa Sungai Tohor, Kecamatan Tebing Tinggi Timur. Sebelumnya pada Tahun 2015, di Desa Wonosari, Kecamatan Rangsang juga telah dibangun SPAM dengan kapasitas yang lebih besar 30 liter/detik, fasilitas ini diklaim mampu melayani kebutuhan air bersih untuk 2.500 Saluran Rumah (SR) di 5 desa yang ada disekitarnya.

\section{KESIMPULAN}

Dari uraian pembahasan tersebut dapat disimpulkan mengenai strategi kebijakan pengembangan industri sagu berbasis Industri Kecil Menengah (IKM) di Kabupaten Kepulauan Meranti yakni pertama, meliputi skenario penataan lokasi, yaitu melakukan Pertimbangan jarak ke pusat kota dilakukan dalam rangka memperoleh kemudahan fasilitas pelayanan baik dari sisi infrastruktur, sarana penunjang maupun sisi pemasaran. Pusat kota yang memiliki infrastruktur dan fasilitas penunjang yang sudah ada dimanfaatkan untuk mendukung pengembangan sentra IKM, hal ini terkait dengan mencukupi kebutuhan listrik dan air minum serta ketersediaan fasilitas keuangan (perbankan) dan kantor pelayanan pemerintahan yang memberikan jasa pelayanan bagi kegiatan IKM yang pada umumnya berlokasi di Pusat Kota sehingga dapat dipahami bahwa pengembangan Sentra IKM tidak harus membangun seluruh infrastruktur dari tahap awal, selain itu dengan memanfaatkan infrastruktur dan fasilitas pusat kota akan memberikan efek keterpaduan pembangunan dan pemerataan pelayanan pusat kota.

Kedua, rencana penggunaan lahan yaitu alokasi luas lahan untuk mencukupi Ketersediaan lahan yang melebihi batas minimal yang penting untuk kebutuhan lahan di luar kegiatan sekor industri, seperti kebutuhan perumahan tenaga kerja dan fasilitas pendukungnya. Persyaratan lahan yang bersifat clear and clean menuntut pemerintah 
untuk melakukan sertifikasi terhadap lahan yang akan digunakan untuk menjamin kesiapan lahan dan tidak dalam sengeketa tanah/lahan.

Ketiga, pemetaan rencana sistem jaringan transportasi, telekomunikasi, listrik dan air bersih yakni menyiapkan sistem transportasi jalan dan laut yang mengacu pada rencana tata ruang wilayah dan dengan memperhatikan keterhubungan antar kawasan dan atau dalam kawasan perkotaan, dan kawasan perdesaan. Untuk telekomunikasi perlu adanya akses layanan publik kantor pos, jasa pengiriman barang dan tercukupinya akses provider jaringan telpon dan internet yang memadai. Kebijakan pemerintah bidang kelistrikan ditunjukkan untuk meningkatkan kesejahteraan masyarakat dengan melakukan peningkatan daya terpasang pembangkit tenaga listrik serta perluasan jaringan distribusi agar ketersediaan tenaga listrik dalam jumlah yang cukup dengan pelayanan yang baik dapat direalisasikan serta kebutuhan prasarana air bersih yang dikelola oleh PDAM Kabupaten Kepulauan Meranti untuk selalu meningkatkan aspek pelayanan kepada masyarakat dalam rangka mendukung pengembangan industri sagu berbasis IKM..

\section{DAFTAR RUJUKAN}

Alfiyah, N. I. (2019). Pengaruh Penerapan e-Government Pada Pembangunan Smart City di Kabupaten Sumenep. Jurnal Inovasi Ilmu Sosial Dan Politik, 1(2), 88. https://doi.org/10.33474/jisop.v1i2.4800

Aprilianti, R., \& Yuliani, F. (2017). Upaya Pemerintah Kabupaten Kepulauan Meranti dalam Penerapan Peraturan Presiden No. 22 Tahun 2009 Tentang Kebijakan Percepatan Penganekaragaman Konsumsi Pangan Berbasis Sumber Daya Lokal. Jurnal Online Mahasiswa Fakultas Ilmu Sosial Dan Ilmu Politik Universitas Riau, 4(2), 1-14.

Arlis Toselong, M. (2018). (n.d.). Pengembangan Agribisnis Sagu Sebagai Pangan Lokal Berkelanjutan. Program Pascasarjana Magister Agribisnis Universitas Hasanuddin diakses

http://digilib.unhas.ac.id/uploaded_files/temporary/DigitalCollection/YWY0ZDc50 DMzOWQ20Tk3MmZiMzI5YzViMzM5MGMyZjljZjdhMDFhZQ==.pdf.

Barrahima, A. (2017). Dimensi Pengembangan Komoditas Sagu dalam Perspektif Pembangunan Berbasis Sumberdaya Lokal (Issue July). Universitas Papua: Manokwari diakses

dari https://www.researchgate.net/publication/319505490_Dimensi_Pengembangan_K omoditas_Sagu_dalam_Perspektif_Pembangunan_Berbasis_Sumberdaya_Lokal.

Direktorat Jendral Kementerian Pertanian Republik Indonesia. (2016). Statistik Perkebunan Indonesia Sagu 2015 - 2017.

E. Tahitu, Meilvis., Saleh, Amiruddin., P, Lubis., Djuara Susanto, D. (2016). (n.d.). Strategi Pengembangan Kapasitas Pengelola Sagu Di Maluku Tengah Provinsi Maluku. Sosiohumaniora, $18(1)$, $39-46$. https://doi.org/10.24198/sosiohumaniora.v18i1.9355

Hartati, S., Syamsuadi, A., \& Elvitaria, L. (2020). (n.d.). Tranformasi Manajemen Universitas menggunakan Framework Cobit 5 di Era Industri 4.0. Ganaya: Jurnal Ilmu Sosial Dan Humaniora, 3(1), 163-174.

kominfo.kotabogor.go.id.

https://kominfo.kotabogor.go.id/asset/images/web/files/strategi-dan-arahkebijakan.pdf.

Kusuma, P. T. W. W., Indrianti, N., \& Ekafitri, R. (2013). Potensi Tanaman Sagu (Metroxylon sp.) dalam Mendukung Ketahanan Pangan di Indonesia. Jurnal Pangan, 22(1), 61-76. https://doi.org/10.33964/jp.v22i1.78

Novarianto, H., Tulalo, M. A., Kumaunang, J., \& Indrawanto, C. (2014). Varietas Unggul Sagu 
Selatpanjang Meranti. Jurnal Buletin Palma, 15(1), 47-55.

Nursodik, R., Rosnita, R., \& Sayamar, E. (2016). Kemandirian Petani Dalam Berusahatani Sagu Di Desa Tanjung Kecamatan Tebing Tinggi Barat Kebupaten Kepulauan Meranti Provinsi Riau. 13(1), 28-39.

Paiti, A. S. (2017). Upaya Indonesia Mengekspor Sagu Ke Malaysia (Studi Kasus: Kabupaten Kepulauan Meranti). Jurnal Online Mahasiswa Fakultas Ilmu Sosial Dan Ilmu Politik Universitas Riau, 4(2), 1-13.

Purwanto, H. E., Rosnita, R., \& Yulida, R. (2017). Keragaan Agribisnis Sagu Di Desa Tanjung Tebing Tinggi Barat Kabupaten Kepuluan Meranti. Jurnal Agribisnis, 19(2), 116-130. Rifa, A. (2016). Analisis Pemberdayaan Usaha Kecil Menengah Penghasil Produk Berbahan Baku Sagu Di Desa Banglas Kecamatan Riau. 2(2), 140-155.

Suryabrata, S. (1998). Metode penelitian. Jakarta: PT RajaGrafindo Persada.

Syafaruddin. (2008). Efektifitas Kebijakan Pendidikan. Jakarta: Rineka Cipta. 